\title{
Phosphate solubilization and synergism between P-solubilizing and arbuscular mycorrhizal fungi
}

\author{
Edson Luiz Souchie(1), Rosario Azcón(2), Jose Miguel Barea(2), Orivaldo José Saggin-Júnior ${ }^{(3)}$ \\ and Eliane Maria Ribeiro da Silva(3)
}

\begin{abstract}
(1)Centro Federal de Educação Tecnológica, Caixa Postal 66, CEP 75901-970 Rio Verde, GO, Brazil. E-mail: esouchie@yahoo.com.br (2)Estación Experimental del Zaidín, Dep. de Microbiología y Sistemas Simbióticos, 18008 Granada, Spain. E-mail: razcon@eez.csic.es, jmbarea@eez.csic.es (3)Embrapa Agrobiologia, Caixa Postal 74505, CEP 23851-970 Seropédica, RJ, Brazil. E-mail: saggin@cnpab.embrapa.br, eliane@cnpab.embrapa.br
\end{abstract}

\begin{abstract}
The objective of this work was to evaluate the ability of several P-solubilizing fungi to solubilize aluminum phosphate and Araxá apatite as well as the synergism between the P-solubilizing fungus, PSF 7, and arbuscular mycorrhizal fungi to promote clover growth amended with aluminum phosphate. Two experiments were carried out, the first under laboratory conditions and the second in a controlled environmental chamber. In the first experiment, PSF 7, PSF 9, PSF 21 and PSF 22 isolates plus control were incubated in liquid medium at $28^{\circ} \mathrm{C}$ for eight days. On the $2^{\text {nd }}, 4^{\text {th }}$ and $8^{\text {th }}$ day of incubation, $\mathrm{pH}$ and soluble $\mathrm{P}$ were determined. In the second experiment, clover was sowed in plastic pots containing $300 \mathrm{~g}$ of sterilized substrate amended with aluminum phosphate, $3 \mathrm{~g} \mathrm{~L}^{-1}$, in presence and absence of PSF 7 isolate and arbuscular mycorrhizal fungi. A completely randomized design, in factorial outline 2x2 (presence and absence of PSF 7 and arbuscular mycorrhizal fungi) and five replicates were used. In the first experiment, higher $\mathrm{P}$ content was detected in the medium containing aluminum phosphate. PSF 7 is the best fungi isolate which increases aluminum solubilization with major tolerance to $\mathrm{Al}^{3+}$. Clover growth was stimulated by presence of PSF 7 and arbuscular mycorrhizal fungi. There is synergism between microorganisms utilized to improve plant nutrition.
\end{abstract}

Index terms: Aspergillus, Trifolium pratense, Araxá apatite, aluminum phosphate, symbiosis, Glomus.

\section{Solubilização de fosfatos e sinergismo entre fungos solubilizadores de fosfato e micorrízicos arbusculares}

\begin{abstract}
Resumo - O objetivo deste trabalho foi avaliar a capacidade de solubilização de fosfato de alumínio e apatita de Araxá por diversos isolados de fungos solubilizadores de fosfato e o sinergismo entre o fungo solubilizador de fosfato, FSF 7, e fungos micorrízicos arbusculares, na promoção do crescimento de trevo fertilizado com fosfato de alumínio. Dois experimentos foram conduzidos, o primeiro em laboratório e o segundo em câmaras de cultivo. No primeiro experimento, os isolados FSF 7, FSF 9, FSF 21 e FSF 22, mais controle foram incubados em meio líquido, sob agitação, a $28^{\circ} \mathrm{C}$, por oito dias. Avaliou-se o $\mathrm{pH}$ e P solúvel no segundo, quarto e oitavo dia de incubação. No segundo experimento, semeou-se trevo em copos de plástico contendo $300 \mathrm{~g}$ de substrato esterilizado, fertilizado com fosfato de alumínio, $3 \mathrm{~g} \mathrm{~L}^{-1}$, com e sem FSF 7 e fungos micorrízicos. O delineamento foi inteiramente casualizado, esquema fatorial 2x2 (presença e ausência de FSF 7 e fungos micorrízicos), com cinco repetições. No primeiro experimento, foram encontradas maiores quantidades de P solúvel no meio contendo fosfato de alumínio. O FSF 7 aumentou a solubilização desse fosfato. O crescimento do trevo foi favorecido pela presença do FSF 7 e fungos micorrízicos arbusculares, o que evidencia sinergismo entre esses microrganismos.

Termos para indexação: Aspergillus, Trifolium pratense, apatita de Araxá, fosfato de alumínio, simbiose, Glomus.
\end{abstract}

\section{Introduction}

Since phosphorus (P) is commonly involved in adsorption and precipitation reactions in soil, it is the nutrient which presents the lowest mobility rate among the essential nutrients for plants. Consequently, soil P concentration is generally low despite high total $\mathrm{P}$ content (Miyasaka \& Habte, 2001).
Several authors have identified the ability of fungi, mainly of Aspergillus and Penicillium genus, to solubilize phosphates under in vitro conditions (Omar, 1998; Seshadri et al., 2004; Wakelin et al., 2004). That ability is generally associated to the release of organic acids, decreasing the $\mathrm{pH}$ (Seshadri et al., 2004). Moreover, these organic acids can increase considerably $\mathrm{P}$ in the soil solution through the quelation of $\mathrm{Ca}$, Fe and 
$\mathrm{Al}$, change reactions and solubilization of low soluble salts (Gadd, 1999).

The inoculation of $\mathrm{P}$-solubilizing microorganisms is a promising technique because it can increase $P$ availability in soils fertilized with rock phosphates (Reyes et al., 2002). Several authors reported yield increasing on wheat (Whitelaw et al., 1997), onion (Vassilev et al., 1997) and soybean (Abd-Alla \& Omar, 2001) through simple inoculation of P-solubilizing fungi (PSF). Rodríguez et al. (1999) detected highest increase on alfalfa growth cultivated in soil amended with rock phosphate and red beet residues, when Aspergillus niger and Glomus deserticola were inoculated. Vassileva et al. (1998) reported synergism between those microorganisms when a considerable increase in $\mathrm{P}$ absorption and growth of clover (Trifolium repens) was verified. Similarly, coinoculation of Yarowia lipolitica, a P-solubilizing yeast, stimulated considerably mycorrhizal root colonization in tomato by Glomus deserticola (Vassilev et al., 2001).

Ravnskov et al. (1999) also verified an increase on mycorrhizal root colonization in forage legume when Saccharomyces cerevisiae was present. Beyond the phosphate solubilization, many P-solubilizing microorganisms increase the mycorrhizal root colonization by production of specific metabolites as vitamins, amino acids and hormones (Barea et al., 1997). Therefore, there is a demand on studies on this subject, in order to improve the functional knowledge of compatibility of those microorganisms aiming at their coinoculation to increase the nutrition and growth of plant species.

The objective of this work was to evaluate solubilization ability of aluminum phosphate and Araxá apatite by several fungi isolates and the synergism between the PSF 7 isolate and AMF on clover growth amended with aluminum phosphate.

\section{Material and Methods}

Two experiments were carried out, the first under laboratory conditions and the second in a controlled environmental chamber, at Estación Experimental del Zaidín, Granada, Spain, from May to July, 2002.

In the first experiment, the solubilization of Araxá apatite and aluminum phosphate by P-solubilizing microorganisms was quantified on the $2^{\text {nd }}, 3^{\text {rd }}$ and $8^{\text {th }}$ day during incubation time of different PSF isolates (all Aspergillus sp.). The treatments were PSF 7, PSF 9, PSF 21 and PSF 22, plus control. The experiment followed a completely randomized block, in factorial outline $5 \times 2 \times 3$ (five kinds of PSF treatments, two phosphate sources, three-time evaluations), with triplicates per treatment.
The PSF 7 and PSF 9 were isolated from the rhizoplane plus rhizosphere of Mimosa caesalpiniifolia grown in an Argissoil collected in an area of the Atlantic Forest, Paraty, RJ. The PSF 21 and 22 were isolated from the rhizoplane plus rhizosphere of Acacia holosericea grown in a Planosoil collected in Seropédica, RJ. The Araxá apatite (14 $\mathrm{g} \mathrm{kg}^{-1}$ of P) and aluminum phosphate (16 g kg-1 of P) were added $\left(3 \mathrm{~g} \mathrm{~L}^{-1}\right)$ in liquid medium described by Sylvester-Bradley et al. (1982). It resulted in 4.5 and $17 \mathrm{mg} \mathrm{L}^{-1}$ of soluble $\mathrm{P}$ in these liquid medium respectively, while the initial $\mathrm{pH}$ was 6.5. Each erlenmeyer $(250 \mathrm{~mL})$, containing $50 \mathrm{~mL}$ of medium with the phosphate treatments, received $1 \mathrm{~mL}$ of spores suspension containing $10^{8} \mathrm{CFU} \mathrm{mL}-1$ of each PSF isolate. Spores suspension was prepared by the following procedure: each isolate was incubated in Petri dishes (four days, $28^{\circ} \mathrm{C}$, darkness), in GL solid medium, up to Petri dishes basis was covered. The spores were suspended in water plus tween (1\%), using a Drigalsky spatula, quantified using successive dilution and direct counting techniques and diluted till $10^{8} \mathrm{CFU} \mathrm{mL} \mathrm{mL}^{-1}$.

The PSF isolates were incubated at $28^{\circ} \mathrm{C}$, by shaking (190 rpm), and after the second, fourth and eighth day of incubation, $\mathrm{pH}$, soluble $\mathrm{P}$ in the liquid medium and isolates dry biomass were determined. The dry biomass was evaluated by drying out colonies in a stove for three days at $60^{\circ} \mathrm{C}$ and weighed.

In the second experiment, the effect of PSF 7 isolate and arbuscular mycorrhizal fungi on nutrition and growth of clover cultivated in substrate with aluminum phosphate was evaluated. The PSF 7 was chosen because of the best performance, in aluminum phosphate solubilization, in the first experiment.

Clover (Trifolium pratense) was grown in plastic pots containing $300 \mathrm{~g}$ of substrate (washed sand, vermiculite and sepiolite, 1/1/1, v/v/v). Each component was autoclavated $\left(120^{\circ} \mathrm{C}, 20 \mathrm{~min}\right)$ separately. The same amount used in experiment $1,3 \mathrm{~g} \mathrm{~L}^{-1}$ of aluminum phosphate, was mixed to the substrate. Clover was cultivated in the presence and absence of PSF 7, and two mixed species of AMF (Glomus clarum and Glomus geosporum) as experimental treatments. A completely randomized design, in factorial outline 2x2 (presence and absence of PSF 7 and AMF) and five replicates were used.

The mycorrhizal inoculum consisted of soil with spores, mycelia and root fragments colonized by Glomus clarum and Glomus geosporum. Equal proportions were prepared by mixing $300 \mathrm{~mL}$ of soil containing AMF inoculum of G. clarum and G. geosporum, which contained 8 and 20 spores per mL of soil, respectively. 
Both AMF fungi were multiplied using sorghum and corn as trap plants and maintained as a stock culture. An amount of $5 \mathrm{~mL}$ was used per pot and homogenized into the substrate before plant sowing. In the control, $2 \mathrm{~mL}$ per pot of an inoculum filtrate, without AMF propagules, were added to the plant basis. This final filtrate was obtained by mixing $1 \mathrm{~mL}$ of both G. clarum and G. geosporum inoculum filtrates.

After emergence, seedlings were thinned to one plant per pot. Every plant received $1 \mathrm{~mL}$ of Rhizobium trifolii (strain 2152) inoculum. This strain was incubated in liquid medium Ty (Beringer, 1974), till $10^{8} \mathrm{CFU} \mathrm{mL}{ }^{-1}$. Two received inoculum of PSF 7. This isolate was grown in Petri dishes (four days, $28^{\circ} \mathrm{C}$, darkness), in GL solid medium (Sylvester-Bradley et al., 1982) up to Petri basis water + tween (1\%), quantified following the successive dilution technique till $10^{8} \mathrm{CFU} \mathrm{mL}-1$, applying $1 \mathrm{~mL}$ of spore suspension per pot.

The experiment was carried out during 60 days in a controlled environmental chamber under conditions of
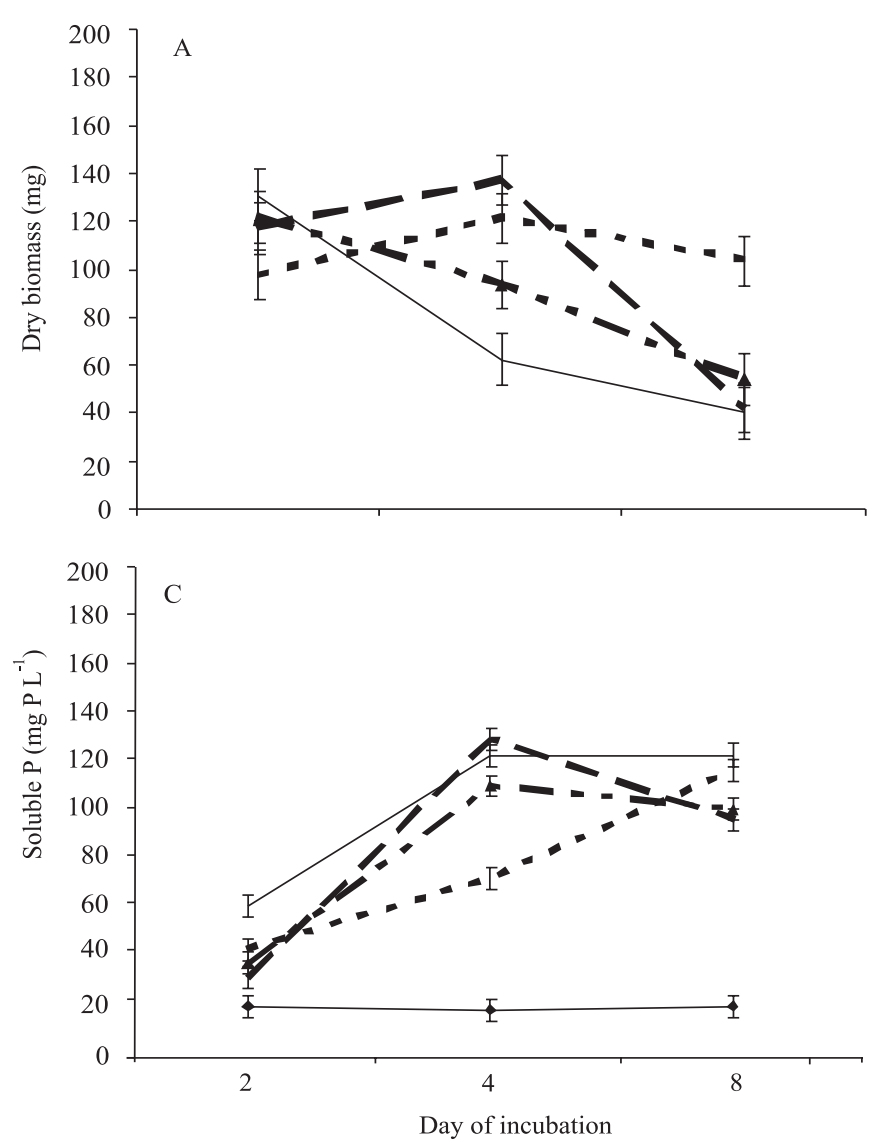
days after inoculation of Rhizobium trifolii, plants was covered. Spores were suspended in a solution of

$50 \%$ relative humidity, day and night temperatures of $27^{\circ} \mathrm{C}$ and $18^{\circ} \mathrm{C}$, respectively, and a photoperiod of 14 hours. Photosynthetic photon flux density was $503 \mu \mathrm{mol} \mathrm{m} \mathrm{s}^{-1}$, as measured with a lightmeter (LICOR, model LI-188B). Twice a week, $25 \mathrm{~mL}$ of nutritive solution (Hewitt, 1966) modified (without N, $10 \%$ of $\mathrm{P}$ and $\mathrm{pH} 5.5$ ) were added per pot.

Every 20 days, plant growth was evaluated through two shoot cuts, determining the shoot fresh and dry weight. In the third cut, plants were harvested and shoot/ root fresh and dry weight, colonized root length (Giovannetti \& Mosse, 1980), number of nodules, $\mathrm{N}$ and P shoot content and indolacetic acid (IAA) concentration on substrate were determined. Data of both experiments were subjected to ANOVA and means were compared by Tukey test $(\mathrm{p} \leq 0.05)$.

\section{Results and Discussion}

At experiment 1, the PSF biomass of isolates incubated with Araxá apatite was higher than those incubated with aluminum phosphate (Figure $1 \mathrm{~A}$ and $\mathrm{B}$ ).
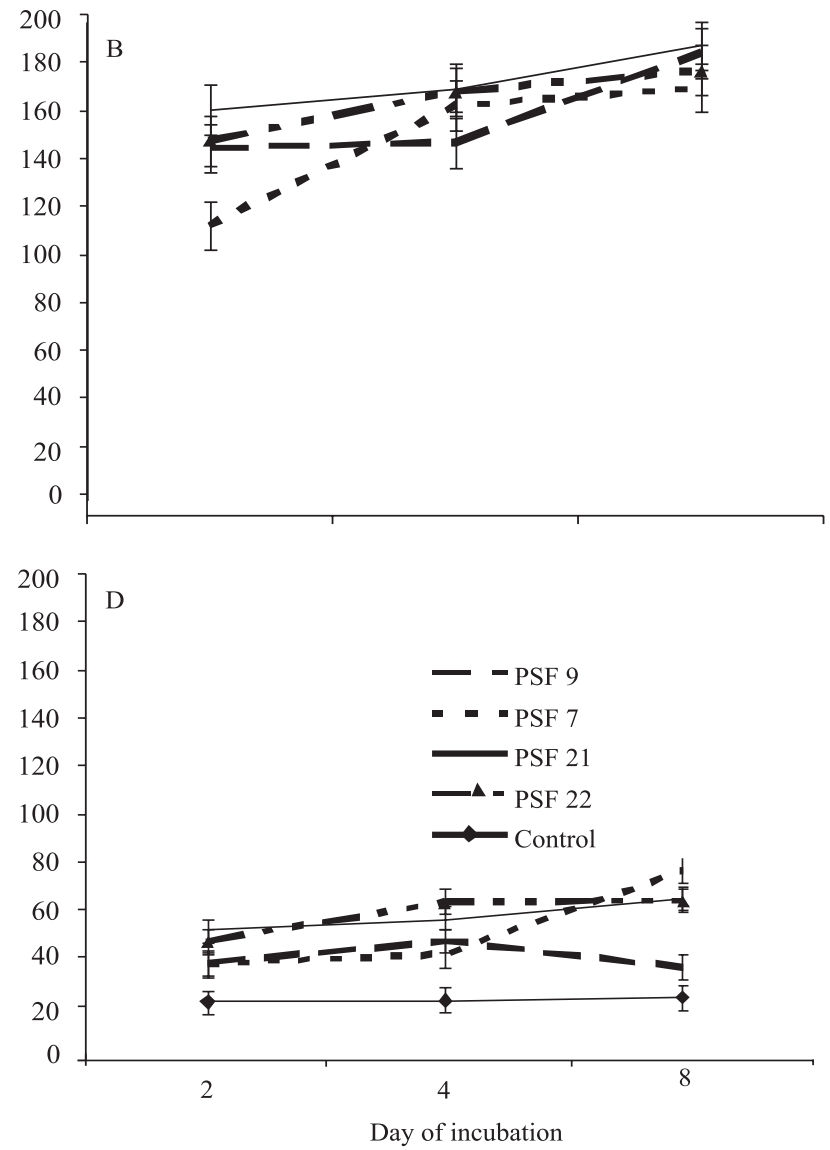

Figure 1. Dry biomass of P-solubilizing fungi (PSF) isolates and soluble P in liquid medium amended with aluminum phosphate (A and C) or Araxá apatite (B and D) on the second, fourth and eighth day of incubation. 
All fungi isolates showed increasing biomass with incubation time in the Araxá apatite treatments. Fungi biomass decreased when incubated with aluminum phosphate, particularly after the fourth day of incubation (Figure $1 \mathrm{~A}$ ). The PSF 7 isolate had different responses comparing to the others, with higher biomass production in the last evaluation time, when incubated with aluminum phosphate (Figure $1 \mathrm{~A}$ ).

Broadly, higher values of soluble $\mathrm{P}$ were found in the medium added with aluminum phosphate than the medium with Araxá apatite (Figure $1 \mathrm{C}$ and D). This was certainly due to higher water solubility of aluminum phosphate than the Araxá apatite. Most PSF isolates incubated with aluminum phosphate showed solubilization peak after four days of incubation. That response was verified in lower intensity when fungi isolates were incubated with Araxá apatite (Figure $1 \mathrm{D}$ ). Isolates PSF 9 and PSF 21 solubilized more than $165 \mathrm{mg} \mathrm{L}^{-1}$ of P (Figure 1 C).

After eight days of incubation, isolates PSF 7 and PSF 21 incubated with aluminum phosphate (Figure 1 C) solubilized more phosphate than others. The PSF 7 isolate showed no solubilization peak on the fourth day of incubation, favoring a considerable soluble $\mathrm{P}$ content on the eighth day of incubation. The same was verified in the medium added with Araxá apatite (Figure 1 D). Among isolates incubated with this apatite, only PSF 9 was not efficient to solubilize it, maintaining levels of soluble P similar to the control on the eighth day of incubation.

The $\mathrm{pH}$ decreased significantly in the medium from the second and fourth day of incubation with most fungi isolates to both phosphate treatments (Table 1). These isolates showed faster growth acidifying the medium in a short time. Among them, PSF 7 demonstrated the lowest ability to decrease $\mathrm{pH}$, particularly up to the fourth day of incubation. The PSF 22 promoted $\mathrm{pH}$ decrease

Table 1. $\mathrm{pH}$ in liquid medium amended with aluminum phosphate or Araxá apatite on the second, fourth and eighth day of incubation of P-solubilizing fungi (PSF) isolates ${ }^{(1)}$.

\begin{tabular}{lllllllll}
\hline PSF & \multicolumn{3}{c}{ Aluminum phosphate } & & \multicolumn{3}{c}{ Araxá apatite } \\
\cline { 2 - 4 } \cline { 7 - 8 } & $2^{\text {nd }}$ day & $4^{\text {th }}$ day & $8^{\text {th }}$ day & & $2^{\text {nd }}$ day & $4^{\text {th }}$ day & $8^{\text {th }}$ day \\
\hline Control & $4.9 \mathrm{aA}$ & $4.3 \mathrm{aB}$ & $4.5 \mathrm{aB}$ & & $5.8 \mathrm{aA}$ & $5.6 \mathrm{aB}$ & $5.8 \mathrm{aA}$ \\
PSF 7 & $3.8 \mathrm{bA}$ & $3.2 \mathrm{bB}$ & $2.9 \mathrm{bC}$ & & $3.7 \mathrm{bA}$ & $3.4 \mathrm{bC}$ & $3.6 \mathrm{bBC}$ \\
PSF 9 & $3,1 \mathrm{cA}$ & $2.6 \mathrm{cB}$ & $2.5 \mathrm{cdB}$ & & $3.3 \mathrm{cA}$ & $3.1 \mathrm{cA}$ & $3.2 \mathrm{cA}$ \\
PSF 21 & $3.3 \mathrm{cA}$ & $2.5 \mathrm{cB}$ & $2.7 \mathrm{bcB}$ & & $3.4 \mathrm{cA}$ & $3.2 \mathrm{cB}$ & $3.2 \mathrm{cB}$ \\
PSF 22 & $3.4 \mathrm{cA}$ & $2.4 \mathrm{cB}$ & $2.4 \mathrm{~dB}$ & & $3.3 \mathrm{cA}$ & $2.8 \mathrm{~dB}$ & $2.9 \mathrm{cB}$ \\
\hline
\end{tabular}

(1)Means followed by the same lowercase letter, within columns, or by the same uppercase letter, within a row, are not significantly different (Tukey, $\mathrm{p} \leq 0.05$ ). in highest rates (lower than 2.5), in the medium added with aluminum phosphate, and lower than 3.0, in the medium with Araxá apatite.

Low $\mathrm{pH}$ decrease of the medium promoted by the PSF 7, particularly in the beginning of the incubation, is related to its slow growing process, compared to the others. This can be observed by the scarce biomass production at two days of incubation (Figure $1 \mathrm{~A}$ and $\mathrm{B}$ ) and by the low ability to solubilize $P$ up to the fourth day of incubation (Figure $1 \mathrm{C}$ and D). Although all fungi isolates belonged to the same genus, a variation on the phosphate solubilization was verified. Lapeyrie et al. (1991) suggest that $P$ solubilization ability can be variable into the same fungi species.

Despite slow growth rate and lower acidification of the medium, PSF 7 increased the solubilization of both phosphates after eight days of incubation. It showed the highest biomass production when incubated with aluminum phosphate tolerating high levels of $\mathrm{Al}^{3+}$ in solution. Solubilization ability is commonly related to the biomass production. Gharieb (2000) reported correlation between biomass production by Aspergillus niger and production of oxalic acid under in vitro conditions.

Over acidification in the medium and release of toxic levels of some metals during the phosphate solubilization can affect the growth, physiology and metabolism of the fungi (Karamushka et al., 1996). Moreover, apatites contain some heavy metals as $\mathrm{Cd}, \mathrm{Ni}, \mathrm{Pb}, \mathrm{Zn}$ and $\mathrm{Cu}$ (Amaral Sobrinho et al., 1992) that can inhibit the growth of microorganisms. Several authors have reported sinergistic or antagonist interactions among different metals and fungi (Krantz-Rülcker et al., 1996; Hartley et al., 1997).

In the experiment 2 , shoot dry matter was significantly higher when plants were in presence of PSF 7 and AMF (Table 2). For the root dry biomass, the interaction between PSF 7 and AMF was not verified. However, a significant increase (47\%) on the root dry biomass was

Table 2. Shoot dry matter (total of three cuts) $\left(\mathrm{mg} \mathrm{plant}^{-1}\right)$ of clover in presence (+) and absence (-) of PSF 7 and arbuscular mycorrhizal fungi (AMF) $)^{(1)}$.

\begin{tabular}{|c|c|c|c|}
\hline \multirow[t]{2}{*}{ AMF } & \multicolumn{2}{|c|}{ PSF 7} & \multirow[t]{2}{*}{ Increase $(\%)$} \\
\hline & - & + & \\
\hline - & $358 \mathrm{aA}$ & $365 \mathrm{bA}$ & 2 \\
\hline+ & $395 \mathrm{aB}$ & $865 \mathrm{aA}$ & 119 \\
\hline Increase $(\%)$ & 10 & 137 & \\
\hline
\end{tabular}

(1) Means followed by the same lowercase letter, within columns, or by the same uppercase letter, within a row, are not significantly different (Tukey, $\mathrm{p} \leq 0.05$ ). 
verified in presence of PSF 7 while the AMF only effect was not observed.

In relation to the shoot $\mathrm{N}$ and $\mathrm{P}$ content, a little effect of the treatments was verified. Only plants with PSF 7 resulted in a higher $\mathrm{N}$ content $\left(2.9 \mathrm{~g} \mathrm{~kg}^{-1}\right)$ than in the control plants $\left(2.5 \mathrm{~g} \mathrm{~kg}^{-1}\right)$. In relation to the $\mathrm{P}$ content, plants in presence of PSF 7 showed $1.0 \mathrm{~g} \mathrm{~kg}^{-1}$ and the control plants, $1.1 \mathrm{~g} \mathrm{~kg}^{-1}$, without effect of fungus inoculation. There was no difference between mycorrhizal and non-mycorrhizal plants in shoot $\mathrm{N}$ and $\mathrm{P}$ content. Evaluating the total $\mathrm{N}$ and $\mathrm{P}$ content, an improvement from the dual inoculation was verified. This synergism increased the $\mathrm{N}$ and $\mathrm{P}$ quantity by 110 and $225 \%$, respectively.

No significant differences were found for the interaction between PSF 7 and AMF for the number of nodules and IAA content in the substrate. Therefore, only the main effects were evidenced (Table 3). A significant increase in the IAA substrate content in presence of PSF 7 (175\%) and AMF (86\%) was verified. The mycorrhizal root colonization was $23 \%$ for plants inoculated with PSF 7 and 15\% for the control, despite significant difference had not been verified.

A synergism between PSF 7 and AMF, which resulted in an increase of clover growth in presence of aluminum phosphate was detected. Probably the PSF 7 solubilized this phosphate, as observed in the experiment 1 , making $\mathrm{P}$ available to the soil solution. It favored its absorption by AMF, resulting in improvement on plant growth. The absence of effect on shoot P content, when only PSF 7 was inoculated, indicates that the solubilization did not occur in large scale. Another possibility is that the addition of nutrient solution ( $10 \%$ of $\mathrm{P})$ was sufficient for the non-inoculated plants to maintain considerable tissue $\mathrm{P}$ content, or the synergism between AMF and PSF 7 was not nutritional. Richardson (2001) suggests that the plant growth promotion, as consequence of the microbial

Table 3. Indolacetic acid (IAA) in substrate cultivated with clover, and number of nodules in plants in presence $(+)$ or absence (-) of PSF 7 and $\mathrm{AMF}^{(1)}$.

\begin{tabular}{|c|c|c|c|c|}
\hline \multirow[t]{2}{*}{ Inoculation } & \multicolumn{2}{|c|}{ PSF 7 effect } & \multicolumn{2}{|c|}{ AMF effect } \\
\hline & $\begin{array}{c}\text { IAA } \\
\left(\mu \mathrm{g} \mathrm{mL}^{-1}\right)\end{array}$ & $\begin{array}{l}\text { Nodules } \\
\text { (no. plant }{ }^{-1} \text { ) }\end{array}$ & $\begin{array}{c}\text { IAA } \\
\left(\mu \mathrm{g} \mathrm{mL}^{-1}\right)\end{array}$ & $\begin{array}{l}\text { Nodules } \\
\text { (no. plant }{ }^{-1} \text { ) }\end{array}$ \\
\hline - & $0.16 b$ & $426 \mathrm{a}$ & $0.21 b$ & $416 \mathrm{a}$ \\
\hline+ & $0.44 \mathrm{a}$ & $470 \mathrm{a}$ & $0.39 \mathrm{a}$ & $480 \mathrm{a}$ \\
\hline Increase (\%) & 175 & 10 & 86 & 15 \\
\hline
\end{tabular}

(1)Numbers within columns followed by the same letter are not significantly different (Tukey, $\mathrm{p} \leq 0.05$ ). inoculation, can not necessarily be associated to the $\mathrm{P}$ solubilization, commonly observed under laboratory conditions. Mechanisms such as production of phytohormons, vitamins or amino acid can be involved in the P-solubilizing microorganisms effect (Barea et al., 1997; Bowen \& Rovira, 1999).

If aluminum phosphate is solubilized, the $\mathrm{Al}^{3+}$ ion becomes also available in the soil solution, causing toxic effects to PSF 7 and plants. However, the PSF 7 is an isolate that demonstrated tolerance to $\mathrm{Al}^{3+}$ under in vitro conditions (Experiment 1). Therefore, possible toxic effects of this ion on plant nutrition could be inhibited by inoculation of this fungus. On the absence of PSF 7, inoculation of AMF was not effective. In soils containing elevated concentrations of toxic metals, mycorrhizae often increase the metal resistance of host plants (Lux \& Cumming, 2001).

Mechanisms conferring metal resistance, however, are unclear and will most likely differ among metals and perhaps fungi (Kelly et al., 2005). Stress resistance of host plants under metal exposure may be related to increased P uptake (Lux \& Cumming, 2001). In this study, PSF 7 inoculation can have provided an increase on available P, improving plant growth (Table 2). Moreover, the PSF 7 can be lessened the $\mathrm{Al}^{3+}$ toxicity through the immobilization, at least partially, of this ion on its biomass, improving clover growth.

Several authors relate considerable benefits to plant nutrition with inoculation of P-solubilizing fungi (Whitelaw et al., 1997; Abd-Alla \& Omar, 2001, Reyes et al., 2002). Other authors reported a better plant growth through coinoculation of PSF and AMF compared to the single inoculation of these microorganisms (Omar, 1998; Osorio \& Habte, 2001). Further researches should be carried out to confirm the tolerance ability of the PSF 7 and its benefit for plant nutrition under non-sterilized substrate conditions.

\section{Conclusions}

1. The isolate of P-solubilizing fungi PSF 7 increases aluminum solubilization along the incubation time and is more tolerant to $\mathrm{Al}^{3+}$ in solution.

2. Aluminum phosphate solubilization decreases after the fourth day for most isolates utilized.

3 . The clover growth is benefited by coinoculation of PSF 7, Glomus clarum and Glomus geosporum, in presence of aluminum phosphate, evidencing synergism among these microorganisms. 


\section{Acknowledgements}

To Capes, for the grant; to Prodetab, for the financial support.

\section{References}

ABD-ALLA, M.H.; OMAR, S.A. Survival of rhizobia/bradyrhizobia and a rock-phosphate-solubilizing fungus Aspergillus niger on various carriers from some agro-industrial wastes and their effects on nodulation and growth of faba bean and soybean. Journal of Plant Nutrition, v.24, p.261-272, 2001.

AMARAL SOBRINHO, N.M.B.; COSTA, L.M.; OLIVEIRA, C.; VELOSO, A.C.X. Metais pesados em alguns fertilizantes e corretivos. Revista Brasileira de Ciência do Solo, v.16, p.270276, 1992.

BAREA, J.M.; AZCÓN-AGUILAR, C.; AZCÓN, R. Interactions between mycorrhizal fungi and rhizosphere microorganisms within the context of sustainable soil-plant systems. In: GANGE, A.C.; BROWN, V.K. (Ed.). Multitrophic interactions in terrestrial systems. Cambridge: Blackwell Science, 1997. p.65-77.

BERINGER, J.E. R-factor transfer in Rhizobium leguminosarum. Journal of General Microbiology, v.84, p.188-197, 1974.

BOWEN, G.D.; ROVIRA, A.D. The rhizosphere and its management to improve plant growth. Advances in Agronomy, v.66, p.1-102, 1999.

GADD, G.M. Fungal production of citric and oxalic acid: Importance in metal speciation, physiology and biogeochemical processes. Advances in Microbial Physiology, v.41, p.47-92, 1999.

GHARIEB, M.M. Nutritional effects on oxalic acid production and solubilization of gypsum by Aspergillus niger. Mycological Research, v.104, p.550-556, 2000.

GIOVANNETTI, M.; MOSSE, B. An evaluation of techniques for measuring vesicular-arbuscular mycorrhizal infection in roots. New Phytologist, v.84, p.489-500, 1980.

HARTLEY, J.; CAIRNEY, J.W.G.; SANDERS, F.E.; MEHARG, A.A. Toxic interactions of metal ions $\left(\mathrm{Cd}^{2+}, \mathrm{Pb}^{2+}, \mathrm{Zn}^{2+} \mathrm{e} \mathrm{Sb}^{3-}\right)$ on in vitro biomass production of ectomycorrhizal fungi. New Phytologist, v.137, p.551-562, 1997.

HEWITT, E.J. Sand and water culture methods used in the study of plant nutrition. $2^{\text {nd }}$ ed. London: Commonwealth Agricultural Bureau, 1966. 547p.

KARAMUSHKA, V.I.; SAYER, J.A.; GADD, G.M. Inhibition of $\mathrm{H}^{+}$efflux from Saccharomyces cerevisiae by insoluble metal phosphates and protection by calcium and magnesium: inhibitory effects a result of soluble metal cations? Mycological Research, v.100, p.707-713, 1996.

KELLY, C.N.; MORTON, J.B.; CUMMING, J.R. Variation in aluminum resistance among arbuscular mycorrhizal fungi. Mycorrhiza, v.15, p.193-201, 2005.
KRANTZ-RÜLCKER, C.; ALLARD, B.; SCHNÜRER, J. Adsorption of IIB-metals by three common soil fungi-comparison and assessment of importance for metal distribution in natural soil systems. Soil Biology and Biochemistry, v.28, p.967-975, 1996.

LAPEYRIE, F.; RANGER, J.; VAIRELLES, D. Phosphate solubilizing activity of ectomycorrhizal fungi in vitro. Canadian Journal of Botany, v.69, p.342-346, 1991.

LUX, H.B.; CUMMING, J.R. Mycorrhizae confer aluminum resistance to tulip-poplar seedlings. Canadian Journal of Forest Research, v.31, p.694-702, 2001.

MIYASAKA, S.C.; HABTE, M. Plant mechanisms and mycorrhizal symbioses to increase phosphorus uptake efficiency. Communications in Soil Science and Plant Analysis, v.32, p.1101-1147, 2001.

OMAR, S.A. The role of rock-phosphate-solubilizing fungi and vesicular-arbuscular mycorrhiza (VAM) in growth of wheat plants fertilized with rock phosphate. World Journal of Microbiology and Biotechnology, v.14, p.211-218, 1998.

OSORIO, N.W.; HABTE, M. Synergistic influence of an arbuscular mycorrhizal fungus and a $\mathrm{P}$ solubilizing fungus on growth and $\mathrm{P}$ uptake of Leucaena leucocephala in an Oxisol. Arid Land Research and Management, v.15, p.263-274, 2001.

RAVNSKOV, S.; LARSEN, J.; OLSSON, P.A.; JAKOBSEN, I. Effects of various organic compounds on growth and phosphorus uptake of an arbuscular mycorrhizal fungus. New Phytologist, v.141, p.517-524, 1999.

REYES, I.; BERNIER, L.; ANTOUN, H. Rock phosphate solubilization and colonization of maize rhizosphere by wild and genetically modified strains of Penicillium rugulosum. Microbial Ecology, v.44, p.39-48, 2002.

RICHARDSON, A.E. Prospects for using soil microorganisms to improve the acquisition of phosphorus by plants. Australian Journal of Plant Physiology, v.28, p.897-906, 2001.

RODRÍGUEZ, R.; VASSILEV, N.; AZCÓN, R. Increases in growth and nutrient uptake of alfalfa grown in soil amended with microbiallytreated sugar beet waste. Applied Soil Ecology, v.11, p.9-15, 1999.

SESHADRI, S.; IGNACIMUTHU, S.; LAKSHMINARASIMHAN, C. Effect of nitrogen and carbon sources on the inorganic phosphate solubilization by different Aspergillus niger strains. Chemical Engineering Communications, v.191, p.1043-1052, 2004.

SYLVESTER-BRADLEY, R.; ASKAWA, N.; LA TORRACA, S.; MAGALHÃES, F.M.M.; OLIVEIRA, L.A.; PEREIRA, R.M. Levantamento quantitativo de microrganismos solubilizadores de fosfato na rizosfera de gramíneas e leguminosas forrageiras na Amazônia. Acta Amazonica, v.12, p.15-22, 1982.

VASSILEV, N.; TORO, M.; VASSILEVA, M.; AZCÓN, R.; BAREA, J.M. Rock phosphate solubilization by immobilized cells of 
Enterobacter sp. in fermentation and soil conditions. Bioresource Technology, v.61, p.29-32, 1997.

VASSILEV, N.; VASSILEVA, M.; AZCÓN, R.; MEDINA, A. Application of free and Ca-alginate-entrapped Glomus deserticola and Yarowia lipolytica in a soil-plant system. Journal of Biotechnology, v.91, p.237-242, 2001.

VASSILEVA, M.; VASSILEV, N.; AZCÓN, R. Rock phosphate solubilization by Aspergillus niger on olive cake-based medium and its further application in a soil-plant system. World Journal of Microbiology and Biotechnology, v.14, p.281-284, 1998.

WAKELIN, S.A.; WARREN, R.A.; HARVEY, P.R.; RYDER, M.H. Phosphate solubilization by Penicillium spp. closely associated with wheat roots. Biology and Fertility of Soils, v.40, p.36-43, 2004.

WHITELAW, M.A.; HARDEN, T.J.; BENDER, G.L. Plant growth promotion of wheat inoculated with Penicillium radicum sp. nov. Australian Journal of Soil Research, v.35, p.291-300, 1997.

Received on October 10, 2005 and accepted on June $1^{\text {st }}, 2006$ 